\title{
Screening and identification of Piper species as rootstocks resistance against the root knot nematode under glasshouse condition
}

\section{Chinnapappa, A Ramar, L Pugalendhi, P Muthulakshmi \& P Vetrivelkalai}

Journal of Agriculture and Ecology

Volume-6 (December, 2018) ISSN: 2456-9410

\section{Journal of Agriculture and Ecology}

ISSN: 2456-9410

Volume: 6

Journal of Agriculture and Ecology (2018) 6: 77-84 http://doi.org/10.53911/JAE.2018.6210 


\title{
Screening and identification of Piper species as rootstocks resistance against the root knot nematode under glasshouse condition
}

\author{
M Chinnapappa ${ }^{1} \nabla$, A Ramar ${ }^{1}$, L Pugalendhi $^{2}$, P Muthulakshmi $^{3}$ \& P Vetrivelkalai ${ }^{4}$ \\ ${ }^{I}$ Department of Spices and Plantation Crops, HC\&RI, TNAU. Coimbatore, Tamil Nadu \\ ${ }^{2}$ Department of Spices and Plantation Crops, HC\&RI, TNAU. Coimbatore, Tamil Nadu \\ ${ }^{2}$ Horticultural Research Station, TNAU, Yercaud \\ ${ }^{3}$ Department of Plant Pathology, TNAU, Coimbatore, Tamil Nadu, \\ ${ }^{4}$ Department of Fruit Crops, HC\&RI, TNAU, Coimbatore, Tamil Nadu \\ Corresponding author: M Chinnapappa, E-mail: chinnshorti@gmail.com
}

\begin{tabular}{l}
\hline Article Info \\
\hline Article history \\
Received: 25 August 2018 \\
Accepted: 03 September \\
2018 \\
Available online: 27 \\
November 2018 \\
\hline
\end{tabular}

Key Words: Piper species, screening, Meloidogyne incognita, resistance.

\begin{abstract}
A study was conducted to evaluate the reaction of different Piper species to root knot nematode (Meloidogyne incognita) and the nematode reproduction were studied in the nematode infested pot culture experiment. Three Piper species viz., Piper colubrinum, Piper argyrophyllum and cultivated Piper nigrum varieties of IISR Sakthi, IISR Thevam, Panniyur-1 and Karimunda were screened. In this study, seven rootstocks were evaluated for resistance based on the growth of pepper cuttings and resistance indexes to Meloidogyne incognita, which were surveyed 45 days after inoculation with M. incognita. The observation was recorded viz., nematode soil population (200 cc), number of galls, number of egg mass, number of females, gall index. All the Piper species show varying degree of response. Out of seven rootstocks used in this experiment IISR Sakthi were found to be highly resistant, Piper colubrinum, IISR Thevam and Karimunda resistant to root knot nematode and these cultivars can be used as a source of resistance. Black pepper (Piper nigrum L.), in particular, suffer extensive damage due to root-knot nematodes, and only a few wild species are known to be resistant. Grafting of cultivated plants to rootstocks of known resistant Piper species rootstocks could be an effective method to resolve this problem.
\end{abstract}

Copyright (C2018 Chinnapappa et al., This is an open access article published under the terms of the Creative Commons Attribution License, which permits unrestricted use, distribution, and reproduction in any medium, provided the original work is properly cited.

Preferred citation: Chinnapappa M, Ramar A, Pugalendhi L, Muthulakshmi P \& Vetrivelkalai P. 2018. Screening and identification of Piper species as rootstocks resistance against the root knot nematode under glasshouse condition. Journal of Agriculture and Ecology, 6: 77-84; http://doi.org/10.53911/JAE.2018.6210.

\section{Introduction}

Black pepper (Piper nigrum L.; $2 \mathrm{n}=2 \mathrm{x}=52$ ) belongs to the family Piperaceae and is one of the oldest and most widely used spices in the world (Gordo et al., 2012). 
Black pepper is recognized as "Black Gold" for its importance and also known as "King of Spices" (Ravindhra et al. 2014). It is originated from tropical evergreen forest of the Western Ghats of India. Black pepper is a globalized condiment used to flavour in all types of cuisines worldwide. The spicy taste is mainly due to the presence of a compound Piperine. Piperine is a pungent alkaloid that enhances the bioavailability of various structurally and therapeutically diverse drugs (Khajuria et al. 2002). It is an important spice crop commercially grown in India, Indonesia, Brazil, Malaysia, Madagascar, Sri Lanka, Thailand and some parts of China. India once considered as a major producer and exporter of black pepper is now pushed backed to second position by Vietnam which is emerging as the world's largest producer of black pepper. In Tamil Nadu, it is grown in Lower Pulney hills, Sheveroy hills, Nilgiris and parts of Kanyakumari.

Slow decline, which was earlier known as slow wilt, is considered as fungal nematode complex coupled with soil moisture stress and malnutrition (Nambiar \& Sarma 1977).The role of plant parasitic nematodes in 'slow wilt' was reported by(Ramana, Mohandas, et al. 1987). (Eapen et al. 2005) listed several nematodes that are associated with black pepper. Among them, the most serious are Radopholus similis and Meloidogyne incognita. Slow decline is rather complex due to not only a species of nematode or fungi, but an interaction of nematode and fungi viz., Radopholus similis, Meloidogyne ingconita, Fusarium solani in roots of black pepper suppressed by slow decline (Aravind et al., 2010). On an average, 70 per cent of Piper vine in Kerala and 54 per cent of Piper vine respectively Karnataka were found to be infested with Meloidogyne incognita and both apparently healthy and slow decline affected vines harbored high population of the nematodes (Ramana \& Eapen 1995; Roshna 2013) reported that crop loss up to 30.5 to 46.7 percent due to nematode in Kerala. Application of nematicides reduces disease infestation but the usage of chemical agents reduces the fertility of soil, high in cost, poses health hazard, if not handled properly and reduces the quality of the produce. Conventional breeding programmes to develop black pepper varieties resistant to root knot nematode have not been successful so far, since high degree resistance is lacking in the available germplasm resources. Another viable option is to exploit this resistant wild species as the rootstock and grafting with the released high yielding cultivars as scions

\section{Materials and Methods}

The present investigation on "Screening of different Piper species for root knot nematode resistance" was carried out from August 2017 to May 2018 at Horticultural Research Station, TNAU, Yercaud. To raise the rootstocks of two node cuttings of Piper colubrinum, Piper argyrophyllum, IISR Sakthi, IISR Thevam, Panniyur 1 and Karimunda were planted in polythene bag containing a mixture of sand, soil and FYM (1:2:1) for screening under glasshouse condition. The treatments were imposed in a Completely Randomized Design (CRD) with three replications. 
Treatments such as $\mathrm{T}_{1}$-Piper colubrinum, $\mathrm{T}_{2}$-Piper argyrophyllum, $\mathrm{T}_{3}$ - IISR Sakthi, $\mathrm{T}_{4}$ - IISR Thevam, $\mathrm{T}_{5}-$ Panniyur 1 and $\mathrm{T}_{6}$ Karimunda.

\section{Maintaining of pure culture of $M$. incognita}

Samples of root bearing galls along with their rhizospheric soils were collected from $M$. incognitia infested tomato plants and using standard sampling method and brought to the laboratory. Isolation of $M$. incognita was done by Cobb's decanting and sieving method and modified Baermann's funnel technique (Cobb 1918; Schindler 1961). The $M$. incognita was identified microscopically by examining the perineal pattern of females. Highly susceptible black pepper variety Panniyur-1 was used for maintain of pure culture of $M$. incognita. Plants of black pepper (Panniyur-1) were raised in the pots filled with sterilized sand, soil and well decomposed FYM in the ratio of $1: 2: 1$. The potted plants were inoculated with $\mathrm{J}_{2}$ of $M$. incognita at 2-3 per gram of soil and maintained for further studies.

\section{Inoculation}

The method of Sasser et al. (1957) was followed for inoculating nematodes. Two month old pure culture of root knot galls formed by Meloidogyne incognita in Panniyur-1 were taken and sliced. Such cut pieces of galls $(0.5 \mathrm{~g})$ were placed inside the holes made around the plants near the root zone. Egg masses of Meloidogyne incognita were removed from pepper roots with forceps placed in petri-plates containing distilled water and incubated for 48 hours under laboratory condition. The hatched juveniles were collected and pipette into $2 \mathrm{~cm}$ deep depression made in the rhizosphere of the plants and then covered with sterile sand. Each pot was inoculated at the rate of one juvenile $\mathrm{J}_{2} / \mathrm{g}$ of soil one week after transplanting. In the case of fungus nematode complex studies, the nematodes were inoculated one week prior to the inoculation of the fungus.

\section{Assessment of nematode population in roots}

The roots were uprooted 45 days after inoculation and washed free of soil, stained with acid fuschin lactophenol and cleared in plain lactophenol for 48 hours. The number of galls and egg mass per root system was assessed under a binocular stereo microscope. The root galls were dissected out of from root and microscopic examination to determine the number and sex of different juvenile stages. The numbers of eggs present in an egg mass per root system were counted after dispersal in a drop of clear lactophenol.

\section{Gall index}

The plants were removed 30 days after inoculation with the entire root system intact and washed free of soil. The number of root knot galls and egg masses were assessed replication wise. Grades were given depending on the extent of galls observed following the procedure given by Taylor \& Sasser (1978).

\begin{tabular}{ccl}
\hline $\begin{array}{c}\text { Number of } \\
\text { galls }\end{array}$ & $\begin{array}{c}\text { Gall } \\
\text { index }\end{array}$ & Plant response \\
\hline No galls & 0 & $\begin{array}{l}\text { Immune } \\
\text { Highly } \\
\text { resistant } \\
1-2\end{array}$ \\
$3-10$ & 2 & Resistant
\end{tabular}




\begin{tabular}{ccl}
$11-30$ & 3 & $\begin{array}{l}\text { Moderately } \\
\text { resistant } \\
31-100\end{array}$ \\
$>100$ & 5 & $\begin{array}{l}\text { Susceptible } \\
\text { Highly } \\
\text { susceptible }\end{array}$ \\
\hline
\end{tabular}

\section{Estimation of nematode population in soil}

The soil sample $(200$ cc $)$ was collected and processed by Cobb's decanting and sieving followed by modified Baermann's funnel method (Cobb 1918; Schindler 1961). Soil population was assessed at 45 days after inoculation.

\section{Results and Discussion}

All the rootstocks and scions developed characteristic galls caused by $M$. incognita. Significant differences were noticed among the rootstocks and scions for number of galls per 5 gram of root, number of egg mass per 5 gram of roots, number of females per galls and nematode population in soil (200 cc). The performance of rootstocks and scions for soil nematode population per $200 \mathrm{cc}$ soil recorded at 45 days after inoculation, ranged from 18.0 to 149 . The data indicated that significantly lower number of nematode population was noticed in IISR Sakthi rootstock (18.00 per $200 \mathrm{cc}$ of soil, followed by Piper colubrinum rootstock (31.2 per $200 \mathrm{cc}$ of soil) whereas highest population was recorded in Piper argyrophyllum rootstock (168.3 per $200 \mathrm{cc}$ of soil) from table. 1. Koshy and Sundaraju, (1979) revealed that screened seven cultivars of pepper against $M$. incognita and reported the variety Panniyur1 was the most susceptible, recording 91.4 per cent root reduction and 7.6 - fold increase in nematode population.

The mean data of number of galls per $5 \mathrm{~g}$ of roots were observed on 45 days after inoculation, ranged from 1.92 to 70.30 . The absence of gall was observed in IISR Sakthi rootstock and the lowest galls were observed in IISR Thevam rootstock (4.00) followed byKarimunda scion (6.30) and the highest number of galls were recorded in Piper argyrophyllum rootstock 70.30 and followed by Panniyur 1 scion (66.70) from table. 1. The least number of galls observed in IISR Sakthi may be explained due to the resistance mechanism of IISR Sakthi which could not support the juveniles of $M$. incognita which has the short life cycle of 30 days Use of resistant rootstocks, in addition to reduction of plant damage caused by nematodes, may reduce nematode population in soil (Thies \& Fery 1998). On the other hand, the susceptible cultivars could support the population of $M$. incognita in their roots. The performance of Piper species of rootstocks and scions for number of egg mass per 5 gram of root ranged from 1.92 to 33 . The lowest number of egg mass were observed in IISR Sakthi and IISR Thevam rootstock (2) and followed by Piper colubrinum rootstock (4). The highest number of eggmass were recorded in Piper argyrophyllum rootstock (33) and followed by Panniyur-1 scion (5 numbers per 5 gram of roots) at 45 days after inoculation. Venkitesan \& Setty (1978) reported that the wild collection of $P$. argyrophyllum recorded more number of galls, soil population, females and eggmass. 
Number of females per gall was observed in different Piper species of rootstocks and scions at 45 days after inoculation. The lowest number of females per gall (3.00) was observed in IISR Sakthi and IISR Thevam followed by Piper colubrinum rootstock and Karimunda scion. The highest number of females per gall was recorded in Piper argyrophyllum rootstock (11.00) and Panniyur-1 scion (9.00) (Table.1).

\section{Gall index}

Parameters like root knot index and soil nematode population were used to evaluate the resistance or susceptibility of Piper species of rootstocks and scions against $M$. incognita. The results revealed that IISR Sakthi rootstock gall index (1) of attaining a reaction category of 'Highly Resistant' (HR). IISR Thevam rootstocks recorded the gall index of ' 1 ' and its attaining a reaction category of 'highly resistant' (HR).Piper colubrinum rootstock and Karimunda scion recorded the gall index of ' 2 ' the reaction category of resistant(R). A gall index of 4 was observed in Piper argyrophyllum rootstock and Panniyur 1 scion which attained the reaction category of susceptible (S) (Table.1). M. incognita which was multiplied in Panniyur-1 roots was used for screening the genotypes in the present investigation in the pots. Similar methods were followed in earlier pepper screening studies (Sasser et al. 1957; Ramana \& Mohandas 1989 ; Haldhar et al. 2015). Hence the, screening techniques employed in the present study is appropriate.

Table 1. Reaction of rootstocks and scions of Piper species to Meloidogyne incognita

\begin{tabular}{|c|c|c|c|c|c|c|c|}
\hline Treatments & Status & $\begin{array}{c}\text { Soil } \\
\text { population } \\
(200 \mathrm{cc})\end{array}$ & $\begin{array}{l}\text { No. of } \\
\text { galls / } \\
5 \mathrm{~g} \text { of } \\
\text { roots }\end{array}$ & $\begin{array}{l}\text { Egg } \\
\text { mass / } \\
5 \mathrm{~g} \text { of } \\
\text { roots }\end{array}$ & $\begin{array}{c}\text { No. of } \\
\text { females } \\
\text { / gall }\end{array}$ & $\begin{array}{l}\text { Root } \\
\text { Knot } \\
\text { Index } \\
\text { (RKI) }\end{array}$ & $\begin{array}{c}\text { Level of } \\
\text { resistance } \\
*\end{array}$ \\
\hline Piper colubrinum & \multirow{6}{*}{ 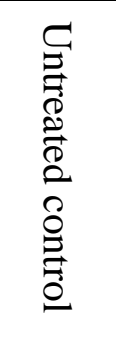 } & - & - & - & - & - & - \\
\hline Piper argyrophyllum & & - & - & - & - & - & - \\
\hline IISR Sakthi & & - & - & - & - & - & - \\
\hline IISR Thevam & & - & - & - & - & - & - \\
\hline Karimunda & & - & - & - & - & - & - \\
\hline Panniyur-1 & & - & - & - & - & - & - \\
\hline Piper colubrinum & \multirow{6}{*}{ 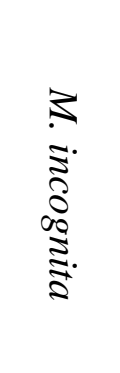 } & 31.20 & 7.20 & 4 & 3 & 2 & $\mathrm{R}$ \\
\hline Piper argyrophyllum & & 168.20 & 70.30 & 33 & 11 & 4 & $S$ \\
\hline IISR Sakthi & & 18.00 & 1.92 & 2 & 2 & 1 & HR \\
\hline IISR Thevam & & 46.30 & 4.00 & 2 & 2 & 2 & $\mathrm{R}$ \\
\hline Karimunda & & 38.10 & 6.30 & 5 & 3 & 2 & $\mathrm{R}$ \\
\hline Panniyur-1 & & 149.40 & 66.70 & 27 & 9 & 4 & $S$ \\
\hline
\end{tabular}

* I- Immune HR- Highly resistant $\quad \mathrm{R}$ - Resistant $\quad$ MR- Moderately resistant S - Susceptible


Journal of Agriculture and Ecology, 2018, Vol.6, 77-84

http://saaer.org.in

\begin{tabular}{|c|c|c|c|}
\hline Gall index & $\begin{array}{l}\text { 0- Immune } \\
\text { 4- Susceptible }\end{array}$ & $\begin{array}{l}\text { 1- Highly } 2 \text { - Resistant } \\
\text { resistant } \\
\text { 5- Highly susceptible }\end{array}$ & $\begin{array}{l}3 \text { - Moderately } \\
\text { resistant }\end{array}$ \\
\hline
\end{tabular}

Fig. 1 Root galls producing by Meloidogyne incognita in different rootstock and scion materials

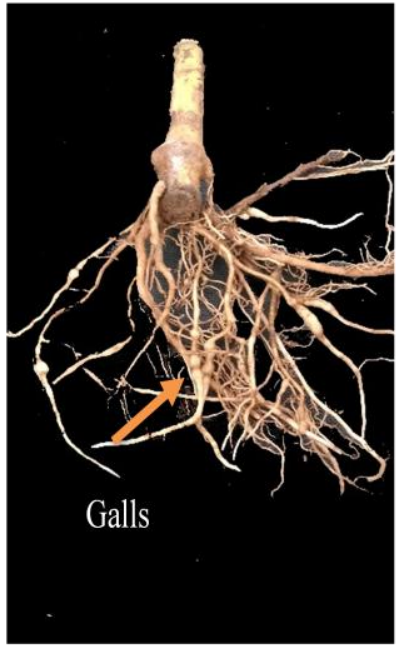

Panniyur 1

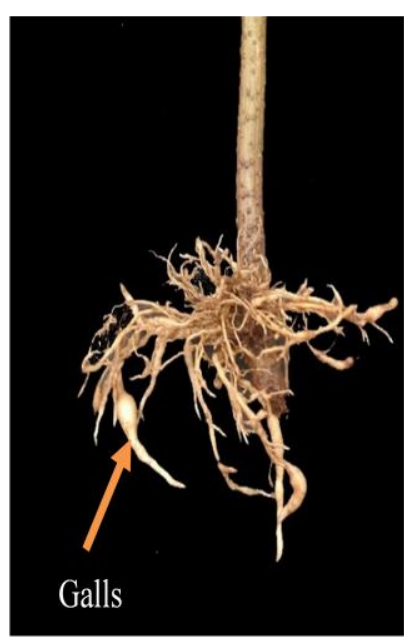

Piper argyrophyllum

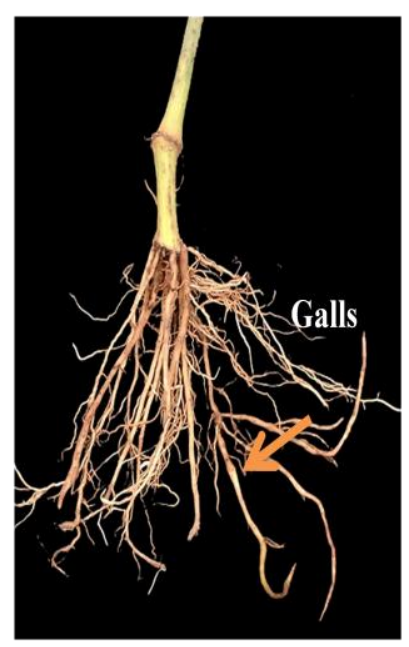

Karimunda

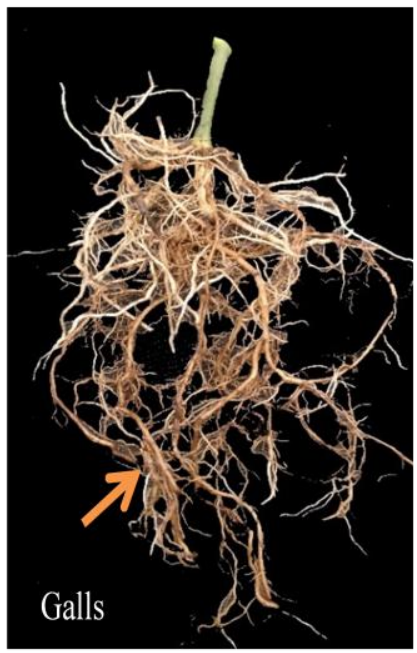

IISR Sakthi

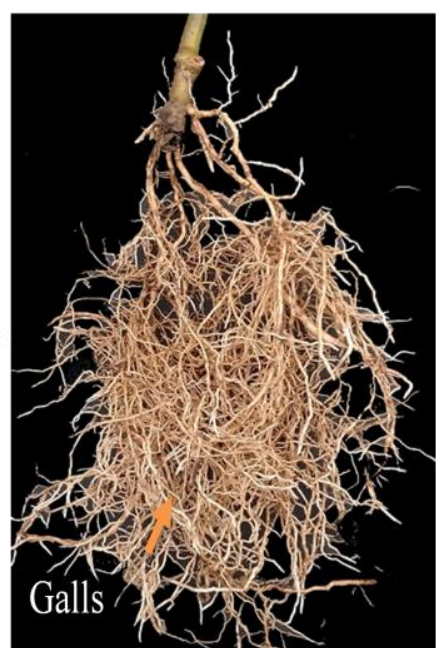

Piper colubrinum

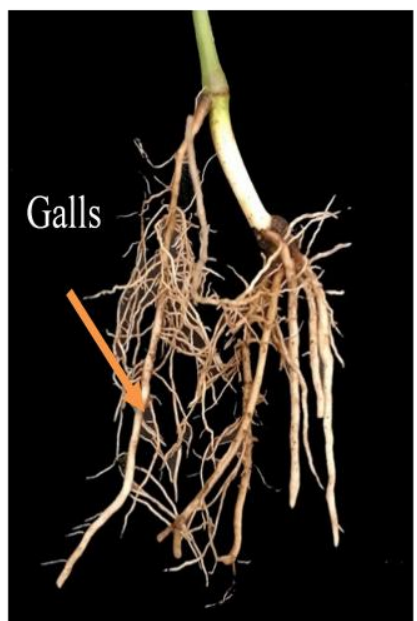

IISR Thevam 
a. Root galls and adult females of $M$. incognita in Piper argyrophyllum

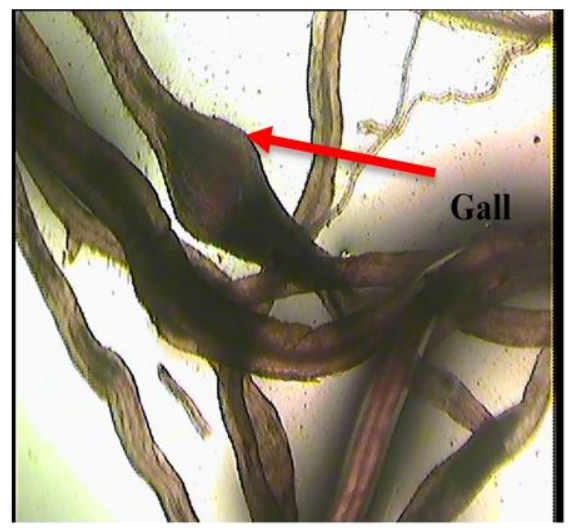

b. Presence of adult female of $M$. incognita on the galled root

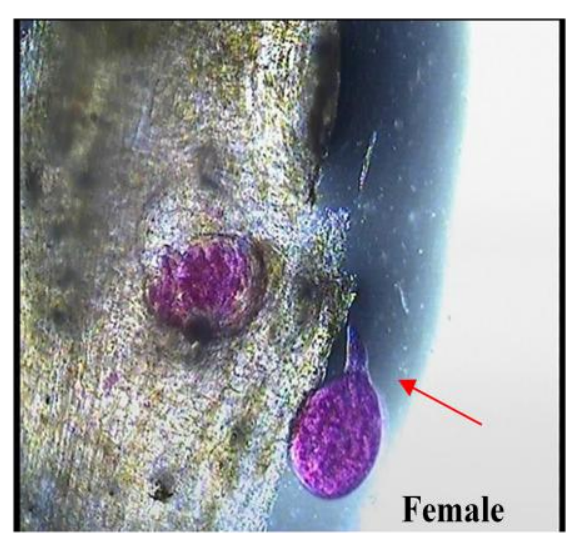

c. Presence of eggmass on the galled roots

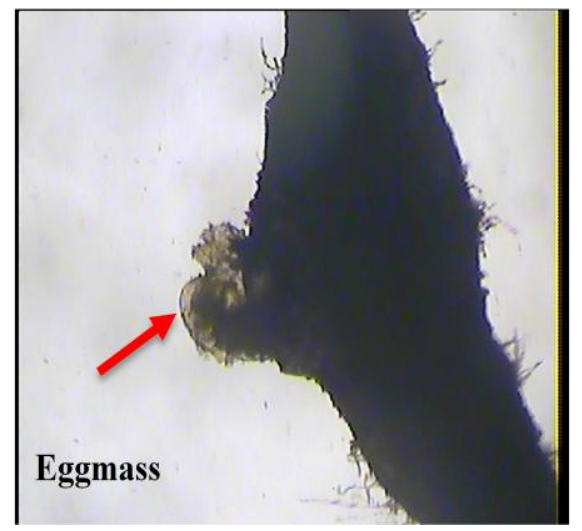

\section{Conclusion}

The findings of the present study revealed that Piper colubrinum, cultivated Piper nigrum varieties of IISR Sakthi and Karimunda showed resistant reaction. Panniyur-1 of black pepper variety is widely cultivated among Yercaud farmers, but Panniyur 1 variety is susceptible to root knot nematode. Hence, grafting of Panniyur-1 with root knot nematode resistant rootstock will directly aid in controlling the nematode and thereby increasing the yield.

\section{References}

Aravind R, Eapen S, Kumar A, Dinu A \& Ramana K. 2010. Screening of endophytic bacteria and evaluation of selected isolates for suppression of burrowing nematode (Radopholus similis Thorne) using three varieties of black pepper (Piper nigrum L.). Crop Protection, 29(4): 318-324. 
Cobb N A. 1918. Estimating the nematode population of soil. Agric. Tech.Circ.1: 1-48.

Eapen SJ, Beena B \& Ramana K. 2005. Tropical soil microflora of spice-based cropping systems as potential antagonists of root-knot nematodes. Journal of Invertebrate Pathology, 88(3): 218-225.

Gordo SM, Pinheiro DG, Moreira EC, Rodrigues SM, Poltronieri MC, De Lemos OF \& Schneider H. 2012. Highthroughput sequencing of black pepper root transcriptome. BMC plant biology, 12(1): 168.

Haldhar SM, Choudhary BR, Bhargava R \& Gurjar K. 2015. Host plant resistance (HPR) traits of ridge gourd (Luffa acutangula (Roxb.) L. against melon fruit fly, (Bactrocera cucurbitae (Coquillett)) in hot arid region of India. Scientia Horticulturae, 194, 168-174.

Khajuria A, Thusu N \& Zutshi U. 2002. Piperine modulates permeability characteristics of intestine by inducing alterations in membrane dynamics: influence on brush border membrane fluidity, ultrastructure and enzyme kinetics. Phytomedicine, 9(3): 224-231.

Koshy PK \& Sundaraju P. 1979. Response of seven black pepper cultivars to Meloidogyne incognita. Nematology Medit, 7: 123-248.
Nambiar K \& Sarma Y. 1977. Wilt diseases of black pepper (India). Journal of plantation crops, 5: 92 - 103.

Ramana K \& Mohandas C. 1987. Plant parasitic nematodes associated with black pepper (Piper nigrum L.) in Kerela. Indian Journal of Nematology, 17(1): 62-66.

Ramana KV \& Mohandas C. 1989. Endoparasitic nematodes infesting roots at black pepper (Piper nigrum L.) in two districts at Karnataka, India. International Nematology Network Newsletter, 6: 33-55.

Sasser J, Powers H \& Lucas G. 1957. Effect of root knot nematodes on the expression of black shank resistance in tobacco. Physiopath, 43: 483.

Thies JA \& Fery RL. 1998. Modified expression of the $\mathrm{N}$ gene for southern root knot nematode resistance in pepper at high soil temperature. Journal of American Society for Horticulture Science, 123: 1012-1015.

Venkitesan T \& Setty K. 1978. Reaction of 27 black pepper cultivars and wild forms to the burrowing nematode Radopholus similiscobb., Thorne (India). Journal of Plantation Crops, 7: 17-26. 